The Pakistan Development Review

Vol. XXVII, No. 2 (Summer, 1988)

\title{
Prospects for Expanding Trade between SAARC and ASEAN Countries
}

\author{
KHWAJA SARMAD and RIAZ MAHMOOD*
}

This paper analyses the determinants of trade flows between the countries of the South Asian Association for Regional Cooperation (SAARC) and of the Association of South East Asian Nations (ASEAN). The results show that while the high intensity of bilateral trade of these countries is not explained by high complementarity, a policy of non discriminatory import liberalization in ASEAN countries would significantly benefit the SAARC countries in terms of export expansion.

The economies of the countries of the South Asian Association for Regional Cooperation (SAARC) and of the Association of South East Asian Nations (ASEAN) are characterized by wide inter-regional and intra-regional per capita income inequalities. With the exception of Singapore, the economies of the countries of the two regions have production structures biased heavily in favour of the primary and agricultural sectors. In addition, Indonesia and Malaysia have substantial oilproducing sectors.

\section{Export Structure}

Table 1 shows that, with the exception of Indonesia and Singapore, the exports of agricultural products constitute a major share of the total exports of SAARC and ASEAN countries. Exports of fuel and chemicals play a prominent role in the export structures of Indonesia, Malaysia and Singapore. The exports of manufactures contribute around half or more to the total exports of Pakistan, India, Bangladesh and Singapore.

The differences in comparative advantage between the countries of the two regions are indicated in the last three columns of Table 1, which give Balassa's index

*The authors are Senior Research Economist and Staff Economist respectively, at the Pakistan Institute of Development Economics. An earlier version of this paper was presented at a Workshop on Prospects and Problems of Inter-regional Cooperation organized by the Centre for Policy Research, New Delhi, in February 1987. The authors are grateful to an anonymous referee of this Review for going through this paper. 
Table 1

Export Structure and Revealed Comparative Advantage of SAARC and ASEAN Countries, 1983

\begin{tabular}{|c|c|}
\hline gge of Total & Revealed Comparative Advantage \\
\hline & al \\
\hline
\end{tabular}

\begin{tabular}{lrrrrrl}
\hline Bangladesh & 34.8 & 5.0 & 59.7 & 2.1 & 0.2 & 1.1 \\
India & 40.3 & 4.6 & 54.7 & 2.4 & 0.2 & 1.0 \\
Nepal & 43.5 & 5.2 & 43.3 & 2.6 & 0.2 & 0.8 \\
Pakistan & 34.0 & 2.8 & 61.8 & 2.1 & 0.1 & 1.2 \\
Sri Lanka & 60.9 & 11.5 & 27.5 & 3.7 & 0.4 & 0.5 \\
Indonesia & 13.9 & 77.0 & 8.0 & 0.8 & 2.7 & 0.2 \\
Malaysia & 42.7 & 29.5 & 27.5 & 2.6 & 1.0 & 0.5 \\
Philippines & 45.2 & 4.1 & 24.8 & 2.7 & 0.1 & 0.5 \\
Singapore & 13.6 & 32.3 & 46.5 & 0.8 & 1.1 & 0.9 \\
Thailand & 62.9 & 1.3 & 34.1 & 3.8 & 0.1 & 0.7 \\
\hline
\end{tabular}

Source: For Tables 1 to 4: United Nations (Various Issues).

Note: Revealed Comparative Advantage (RCA) has been obtained from the following formula:

$$
R C A=\left(X_{i}^{k} / X_{i}\right)\left(X_{w}^{k} / X_{w}\right)
$$

where $X_{w}^{k}$ is the export of product $k$ by country $i$;

$X_{i}$ is the total export of country $i$;

$X_{w}^{k}$ is the world exports of product $k$; and

$X_{w}$ is the total world exports.

of Revealed Comparative Advantage (RCA). A value of greater (less) than one for the RCA index indicates a strong comparative advantage (disadvantage) for the economy in the export of the commodity.

The higher values of the RCA index for agricultural exports of Malaysia, Philippines and Thailand, partly explains the agriculture bias in the export structures of these countries. Similarly, Indonesia's strong comparative advantage in the export of fuels and chemicals (RCA of 2.7), explains the predominance of this category of exports in its total exports.

\section{Trade Intensity}

Given these differences in comparative advantage, it is not difficult to predict the pattern of trade between SAARC and ASEAN countries. Theory suggests that resource-rich countries with a strong comparative advantage in the export of agriculture-biased and primary products would tend to have intense trade relations with countries that are resource-poor but enjoy a comparative advantage in other sectors.

Table 2, which gives the export intensity index of major export groups for the countries of the two regions, bears out these expectations.

In the bilateral trade of SAARC countries with Malaysia and Singapore, agricultural products have high export intensity and, with only a few exceptions, low export intensity with the other ASEAN countries. Exports of fuels and chemicals from SAARC countries to Indonesia and Malaysia, which are major oil producers of ASEAN countries, have very low trade intensity.

In the aggregate inter-regional trade flows, SAARC countries have high export intensity with Malaysia and Singapore, which indicates that the bilateral trade volume is proportionally much greater than would be expected given the importance of the countries in world trade. On the other hand, export intensity of trade of SAARC countries with Indonesia and Philippines is, on the average, much less than one. But export intensity with Thailand is greater than one for Bangladesh, Nepal and Sri Lanka and closer to unity for India and Pakistan.

Given the substantial differences in comparative advantage as indicated by trade data, it is interesting to note that in not all cases is the high trade intensity attributable to high complementarity in bilateral trade. Table 3 shows that this is particularly true about trade from Bangladesh to Malaysia and Singapore, about trade from Nepal to Singapore and Thailand and about trade from Sri Lanka to Malaysia, Philippines and Thailand. Thus, while trade intensity is high the complementarity indices do not indicate that export specialization of the exporting country matches the import specialization of the importing country.

The cause of high bilateral trade intensity is, therefore, to be found in the in dex of bilateral trade bias, which shows the influence of resistances to trade between the exporting and importing countries as compared with the latter's trade with the rest of the world. The figures in Table 4 show that there is a strong bias in SAARC trade towards the ASEAN countries. The average of the bias indices is above 3 which indicates that export trade from SAARC to ASEAN countries is around 3 times more than would be expected after taking into account the region's share in world trade and complementarity of bilateral trade.

\section{Prospects for Trade Growth}

The primary reason for low trade complementarity among some SAARC and ASEAN countries is the protection of less efficient domestic industries, which 
Table 2

Intensity of Bilateral Trade between SAARC and ASEAN Countries Disaggregated by Major Commodity Groups, 1983

\begin{tabular}{lccccc}
\hline \multicolumn{1}{c}{ ASEAN } & Indonesia & Malaysia & Philippines & Singapore & Thailand \\
\hline SAARC & & & & & \\
\hline Bangladesh & 0.2 & 3.5 & - & 8.2 & 0.2 \\
$\quad$ Agriculture & 0.1 & 0.1 & - & 20.3 & 26.9 \\
Fuels and Chemicals & 3.8 & 0.5 & 1.6 & 3.3 & 9.0 \\
Manufactures & 0.4 & 2.7 & 0.4 & 9.4 & 3.2 \\
Total & & & & & \\
India & 0.01 & 8.5 & 0.1 & 2.1 & 1.3 \\
Agriculture & 0.003 & 0.2 & 0.04 & 0.03 & 0.5 \\
Fuels and Chemicals & 0.3 & 1.6 & 0.2 & 0.4 & 0.3 \\
Manufactures & 0.02 & 3.1 & 0.1 & 0.3 & 0.7 \\
Total & & & & & \\
Nepal & - & - & - & 4.5 & 0.7 \\
Agriculture & - & - & - & 0.4 & - \\
Fuels and Chemicals & 1.1 & - & 2.3 & 2.9 & 3.3 \\
Manufactures & 0.1 & - & 0.7 & 2.2 & 1.7 \\
Total & & & & & \\
Pakistan & 0.1 & 2.2 & 0.4 & 3.9 & 2.8 \\
Agriculture & 0.02 & 4.3 & 1.2 & 6.0 & 2.6 \\
Fuels and Chemicals & 0.02 & 0.04 & 0.4 & 0.4 & 2.9 \\
Manufactures & 0.02 & 0.3 & 0.5 & 2.9 & 0.8 \\
Total & 0.4 & 4.6 & 0.1 & 2.2 & 0.8 \\
Sri Lanka & & & & & \\
Agriculture & & & & & \\
Fuels and Chemicals & - & & & & \\
Manufactures & & & & & \\
Total & & & & & \\
\hline
\end{tabular}

Note: The intensity index $\left(I_{i j}\right)$ is defined as the share of country $i$ 's export going to country $j$ relative to the share of country $j$ 's imports in world imports net of imports of country $i$

$$
I_{i j}=\frac{X_{i j}}{X_{i}} / \frac{M_{j}}{M_{w}}-M_{i}
$$

where $\quad X_{i j} \quad$ is country $i$ 's exports to country $j$;

$M_{j} \quad$ is country $j$ 's imports; and

$\left(M_{w}-M_{i}\right) \quad$ is world imports net of country $i$ 's imports.

For discussion of the trade intensity, complimentarity and bias indices see Drysdale and Garnaut (1982).
Table 3

Complementarity in Bilateral Trade between SAARC and ASEAN Countries, 1983

\begin{tabular}{|c|c|c|c|c|c|}
\hline SAARC & Indonesia & Malaysia & Philippines & Singapore & Thailand \\
\hline Bangladesh & 0.02 & 0.5 & - & 2.2 & 2.5 \\
\hline India & 0.004 & 2.1 & 0.6 & 0.1 & 0.3 \\
\hline Nepal & - & - & - & 0.9 & - \\
\hline Pakistan & 1.1 & 6.4 & 0.1 & 1.9 & 1.5 \\
\hline Sri Lanka & - & 0.7 & - & 5.9 & 0.5 \\
\hline
\end{tabular}

Note: The complementarity index of bilateral trade is given by the following formula:

$$
C_{i j}=\Sigma_{k} \frac{X_{i}^{k}}{X_{i}} \cdot \frac{M_{w}-M_{i}}{M_{w}^{k}-M_{i}^{k}} \cdot \frac{M_{i}^{k}}{M_{j}}
$$

where $C_{i j}$ is the complimentarity index, and $X_{i}^{k}$ refers to the export by country $i$ of the $k$ th commodity defined at the 3-digit level of the SITC.

Table 4

\begin{tabular}{|c|c|c|c|c|c|}
\hline SAARC & Indonesia & Malaysia & Philippines & Singapore & Thailand \\
\hline \multicolumn{6}{|l|}{ Bangladesh } \\
\hline Agriculture & - & 22.4 & - & 4.6 & 1.3 \\
\hline Fuels and Chemicals & 22.3 & 6.4 & - & 19.1 & - \\
\hline Manufactures & - & 2.3 & - & 2.2 & - \\
\hline Total & 22.3 & 5.8 & - & 4.3 & 1.3 \\
\hline \multicolumn{6}{|l|}{ India } \\
\hline Agriculture & 0.7 & 0.7 & 0.6 & 2.2 & 3.3 \\
\hline Fuels and Chemicals & 1.6 & 0.9 & 0.8 & 3.3 & 1.7 \\
\hline Manufactures & 4.3 & 2.5 & 0.8 & 3.9 & 1.9 \\
\hline Total & 5.4 & 1.5 & 0.7 & 3.1 & 2.3 \\
\hline \multicolumn{6}{|l|}{ Nepal } \\
\hline Total & - & - & - & 2.5 & - \\
\hline \multicolumn{6}{|l|}{ Pakistan } \\
\hline Agriculture & 0.3 & 0.8 & 0.7 & 0.5 & 0.5 \\
\hline Fuels and Chemicals & - & - & - & 2.6 & - \\
\hline Manufactures & 4.7 & 0.3 & - & 1.3 & 0.6 \\
\hline Total & 0.4 & 0.7 & 0.7 & 1.2 & 0.5 \\
\hline \multicolumn{6}{|l|}{ Sri Lanka } \\
\hline Agriculture & - & 10.6 & - & 0.3 & 22.7 \\
\hline Fuels and Chemicals & - & 5.5 & - & 7.9 & - \\
\hline Manufactures & - & 9.0 & - & 5.8 & 4.8 \\
\hline Total & - & 5.8 & - & 1.0 & 5.0 \\
\hline
\end{tabular}

Bias in Bilateral Trade between SAARC and ASEAN Countries, 1983

Note: Bias indexes have been calculated from the following formula:

$$
B_{i j}=X_{i j} \Sigma_{k}\left[\frac{M_{w}^{k}-M_{i}^{k}}{X_{i}^{k} \cdot M_{j}^{k}}\right]
$$


discriminates against domestic sales of imports and lowers the value of the complementarity index. The average levels of ad valorem tariff rates range from almost zero for Singapore and around 10 percent for Malaysia to around 30 percent for the other ASEAN countries, with the agriculture sector being protected the most.

Given that there are substantial import barriers in ASEAN countries and that SAARC countries have a strong trade bias towards ASEAN countries, this paper has shown that if ASEAN import policy is liberalized, even on a non-discriminatory basis, SAARC countries would tend to gain significantly in terms of export expansion.

\section{REFERENCES}

Drysdale, P., and R. Garnaut (1982). "Trade Intensities and the Analysis of Bilateral Trade Flows in a Many-Country World: A Survey". Hitotsubashi Journal of Economics. Vol. 22, No. 2.

United Nations (Various Issues). Commodity Trade Statistics. New York: Statistical Office. 